\title{
Cannabinoid CB1 Receptor Calibrates Excitatory Synaptic Balance in the Mouse Hippocampus
}

\author{
Krisztina Monory, ${ }^{1}$ Martin Polack, ${ }^{2}$ Anita Remus, ${ }^{2,3}$ Beat Lutz, ${ }^{1}$ and Martin Korte ${ }^{2,3}$ \\ ${ }^{1}$ Institute of Physiological Chemistry, Medical Center of the Johannes Gutenberg University Mainz, 55128 Mainz, Germany, ${ }^{2}$ Zoological Institute, Division \\ Cellular Neurobiology, 38106 Braunschweig, Germany, and ${ }^{3}$ AG NIND, HZI, D-38124 Braunschweig, Germany
}

\begin{abstract}
The endocannabinoid system negatively regulates the release of various neurotransmitters in an activity-dependent manner, thereby influencing the excitability of neuronal circuits. In the hippocampus, cannabinoid type 1 (CB1) receptor is present on both GABAergic and glutamatergic axon terminals. CB1 receptor-deficient mice were previously shown to have increased hippocampal long-term potentiation (LTP). In this study, we have investigated the consequences of cell-type-specific deletion of the CB1 receptor on the induction of hippocampal LTP and on CA1 pyramidal cell morphology. Deletion of CB1 receptor in GABAergic neurons in GABA-CB1-K0 mice leads to a significantly decreased hippocampal LTP compared with WT controls. Concomitantly, CA1 pyramidal neurons have a significantly reduced dendritic branching both on the apical and on the basal dendrites. Moreover, the average spine density on the apical dendrites of CA1 pyramidal neurons is significantly diminished. In contrast, in mice lacking CB1 receptor in glutamatergic cells (Glu-CB1-K0), hippocampal LTP is significantly enhanced and CA1 pyramidal neurons show an increased branching and an increased spine density in the apical dendritic region. Together, these results indicate that the $\mathrm{CB} 1$ receptor signaling system both on inhibitory and excitatory neurons controls functional and structural synaptic plasticity of pyramidal neurons in the hippocampal CA1 region to maintain an appropriate homeostatic state upon neuronal activation. Consequently, if the CB1 receptor is lost in either neuronal population, an allostatic shift will occur leading to a long-term dysregulation of neuronal functions.
\end{abstract}

Key words: cannabinoids; CB1 receptor; dendritic morphology; LTP; spines; synaptic plasticity

\section{Introduction}

To perform its tremendous task, the brain must process and store new information, and at the same time, maintain and retrieve already stored information. To accomplish this, tightly regulated processes must be in place. Synaptic plasticity needs on the one hand cellular mechanisms to regulate and maintain synaptic strength (Bliss and Collingridge, 1993; Malenka and Bear, 2004). On the other hand, homeostatic mechanisms need to operate to restrict the number of synapses which can be potentiated (Turrigiano, 2011). Even the amount of potentiation at single synapses may be restricted and tightly regulated (Roth-Alpermann et al., 2006). Endocannabinoids, acting through cannabinoid type 1 (CB1) receptor, are important negative regulators of transmitter release and as such effectively influence not only synaptic plasticity (Kano et al., 2009; Castillo et al., 2012), but they are also involved in homeostatic processes; e.g., after long-term silencing of neuronal activity (Kim and Alger, 2010) or after excessive activation of excitatory transmission (Bojnik et al., 2012). Expres-

\footnotetext{
Received July 31, 2014; revised Jan. 12, 2015; accepted Jan. 12, 2015.

Author contributions: M.K. designed research; M.P. and A.R. performed research; B.L. contributed unpublished reagents/analytic tools; K.M., M.P., A.R., and M.K. analyzed data; K.M., B.L., and M.K. wrote the paper.

This work was supported in part by CRC 1080 to B.L. We thank Reinhard Huwe for sophisticated technical assistance, and Andrea Conrad, Anne Rohrbacher, and Anisa Kosan for genotyping of mice.

The authors declare no competing financial interests.

Correspondence should be addressed to Dr Martin Korte, TU Braunschweig, Divison of Cellular Neurobiology, Zoological Institute, Spielmannstr 7, D-38106 Braunschweig, Germany. E-mail: m.korte@tu-bs.de.

DOI:10.1523/JNEUROSCI.3167-14.2015

Copyright $\odot 2015$ the authors $\quad 0270-6474 / 15 / 353842-09 \$ 15.00 / 0$
}

sion of CB1 receptor is especially prominent in the hippocampus, where cholecystokinin-positive inhibitory interneurons contain high levels and excitatory pyramidal neurons in the CA 3 and CA1 region provide low levels of this receptor (Marsicano and Lutz, 1999). In fact, genetic disruption of the CB1 receptor leads to an enhanced performance in certain learning paradigms (Marsicano and Lafenetre, 2009; Ruehle et al., 2012). However, CB1-KO mice showed a deficit to unlearn the water maze task (Varvel and Lichtman, 2002) and in extinction of fear memory (Marsicano et al., 2002). Furthermore, administration of cannabinoids impairs certain memory processes via CB1 receptor-mediated signaling, whereas $\mathrm{CB} 1$ receptor blockade enhances performance in several different paradigms (Riedel and Davies, 2005).

Long-term potentiation (LTP) of synaptic transmission is a commonly used model for the synaptic changes that may underlie learning and memory (Citri and Malenka, 2008). Several studies have shown that exogenously applied (endo)cannabinoids act at the CB1 receptor to prevent LTP (Stella et al., 1997; Paton et al., 1998; Hoffman et al., 2007); or to modulate LTP (Navakkode and Korte, 2014). In CB1-KO mice, LTP was increased in vitro and in vivo in the hippocampus (Bohme et al., 2000; Jacob et al., 2012) and in vitro in the amygdala (Marsicano et al., 2002), suggesting that endocannabinoids restrict potentiation. Interestingly, however, LTP stimulation paradigms increase the formation of endocannabinoids in hippocampal slices (Stella et al., 1997). Moreover, the endocannabinoid-elicited decrease of inhibitory transmission facilitates hippocampal LTP by disinhibiting pyramidal neurons 
(Carlson et al., 2002; Chevaleyre and Castillo, 2004). These seemingly contradictory findings might be explained by the fact that the $\mathrm{CB} 1$ receptor signaling in the hippocampus regulates the release of both glutamate and GABA, two neurotransmitters of opposing effects. To understand how the CB1 receptor-mediated regulation of glutamatergic and GABAergic transmission contributes to the fine tuning of synaptic strength, in the present study we measured hippocampal LTP in mice specifically lacking CB1 receptor in cortical glutamatergic (Glu-CB1-KO) or forebrain GABAergic (GABA-CB1-KO) neurons. Furthermore, we have identified morphological substrates of the modified hippocampal neurotransmission elicited by neuronal type-specific deletion of $\mathrm{CB} 1$ receptor.

\section{Materials and Methods}

Animals. Mutant mice, lacking CB1 receptor specifically in cortical glutamatergic (Glu-CB1-KO; Monory et al., 2006) or GABAergic neurons (GABA-CB1-KO; Monory et al., 2006) and their wild-type (WT) littermates in a predominant $\mathrm{C} 57 \mathrm{BL} / 6 \mathrm{~N}$ background ( $>7$ backcrosses into $\mathrm{C} 57 \mathrm{BL} / 6 \mathrm{~N}$ ) were used in this study. Glu-CB1-KO mice were obtained by crossing CB1 ${ }^{\mathrm{f} / \mathrm{f}}$ (Marsicano et al., 2003) with NEX-Cre mice (Kleppisch et al., 2003). GABA-CB1-KO mice were generated by crossing CB1 ${ }^{\mathrm{f} / \mathrm{f}}$ (Marsicano et al., 2003) with Dlx5/6-Cre (Monory et al., 2006). Genotyping was performed by PCR as described for Glu-CB1-KO (Marsicano et al., 2003; Monory et al., 2006), GABA-CB1-KO (Monory et al., 2007), and for CB1 ${ }^{\mathrm{f} / \mathrm{f}}$ (Marsicano et al., 2003). X-gal histochemistry for Dlx5/6Cre (Monory et al., 2006) and NEX-Cre (Monory et al., 2006, Goebbels et al., 2006) showed that Cre recombinase expression in these transgenic mice recapitulates GABAergic and cortical glutamatergic neuronal expression with high accuracy. The detailed anatomical characterization of CB1 receptor expression in GABA-CB1-KO and Glu-CB1-KO was described by Monory et al. (2007) and Bellocchio et al. (2010). The breeding of GABA-CB1-KO is detailed by Massa et al. (2010). In this study, 8 -week-old male adult mice were used. Animals were housed in a temperature- and humidity-controlled room with a $12 \mathrm{~h}$ light/dark cycle and had access to food and water ad libitum. The experimental protocols were performed in accordance with the European Communities Council Directive of 24 November, 1986 (86/609/EEC).

Slice preparation. Mice were anesthetized and decapitated. The brains were transferred into ice-cold carbogenated $\left(95 \% \mathrm{O}_{2}, 5 \% \mathrm{CO}_{2}\right)$ ACSF (124 mm NaCl, $3 \mathrm{~mm} \mathrm{KCl,} 1.25 \mathrm{~mm} \mathrm{KH}_{2} \mathrm{PO}_{4}, 2 \mathrm{~mm} \mathrm{MgSO}_{4}, 2.5 \mathrm{~mm}$ $\mathrm{CaCl}_{2}, 26 \mathrm{~mm} \mathrm{NaHCO}_{3}, 10 \mathrm{~mm} \mathrm{D}(+)$-glucose). Transverse hippocampal slices $(400 \mu \mathrm{m})$ were prepared as described previously (Rösch et al., 2005) and maintained at room temperature in carbogenated ACSF until transfer into a submerged recording chamber (Warner Instruments), perfused with carbogenated $\operatorname{ACSF}\left(32^{\circ} \mathrm{C}\right)$.

Electrophysiological recordings. Field EPSPs were recorded in stratum radiatum of $\mathrm{CA} 1$ with glass micropipettes $(3 \mathrm{M} \mathrm{NaCl}, 10-12 \mathrm{M} \Omega$ ). Synaptic responses were evoked by delivering square pulses $(0.2 \mathrm{~ms}, 20-120$ $\mu \mathrm{A})$ to the Schaffer collaterals with monopolar tungsten electrodes (WPI). Baseline stimulation was delivered at an intensity eliciting a fEPSP of 50\% of the maximal amplitude for $20 \mathrm{~min}$, before a theta-burst stimulation (TBS) was applied. A TBS consisting of four pulses at $100 \mathrm{~Hz}$ was repeated 10 times with $200 \mu$ s intervals. In total, three such stimulus trains were given at $0.1 \mathrm{~Hz}$. Basal synaptic transmission was assessed by determining the strength of postsynaptic responses to afferent fiber stimulation. Presynapse function was assessed with the paired pulse paradigm, delivering two closely spaced stimuli at interstimulus intervals of $160,80,40,20$, and $10 \mathrm{~ms}$. For analysis of fEPSP sizes, the initial slope of the fEPSP was calculated. The ratio of paired pulse facilitation (PPF) was calculated as EPSP2 slope/EPSP1 slope. All values are presented as mean \pm SEM. Differences were detected with two-tailed Student's $t$ test, accepting $p<0.05$ as significant. In LTP experiments, $t$ test was applied to the mean values $55-60 \mathrm{~min}$ (or 175-180 $\mathrm{min}$ ) after TBS. The analysis of fEPSP responses during TBS application was calculated as follows: each TBS consisted of four single pulses at $100 \mathrm{~Hz}$ (defined as a "burst") which were repeated 10 times. We always compared the fourth fEPSP response of the 10th burst between genotypes; this is the $40^{\text {th }}$ fEPSP and therefore the last response in one TBS. This last fEPSP response was calculated in percentage (fourth EPSP response divided by the first EPSP response in that last burst). Significance was tested by ANOVA, followed by a Fisher's post hoc test. Differences under these circumstances would mainly indicate that CA3 axons could not follow faithfully the stimulus, either due to changes in presynaptic properties, or due to defects in myelination.

For all experiments, only littermates were used. All experiments were performed and analyzed without the experimenter knowing the genotype of the preparation.

DiOlistics and morphological analysis. Hippocampal neurons were labeled using Diolistic on acute slices prepared as described above. Slices were immediately fixed after preparation in $4 \%$ PFA overnight at $4^{\circ} \mathrm{C}$. Tungsten particles (50 mg; 0.7 and $1.7 \mu \mathrm{m}$ in diameter; Bio-Rad) were spread on a glass slide, and $100 \mu \mathrm{l}$ of dye solution prepared by dissolving $3 \mathrm{mg}$ of lipophilic dye DiI (Invitrogen) in $100 \mu \mathrm{l}$ of methanol using a hand-held gene gun (Bio-Rad; Helios Gene Gun System). To prevent clusters of large particles from landing on the tissue, a membrane filter (3 $\mu \mathrm{m}$; Millipore) was inserted between the gene gun and the preparation. After shooting, slices were kept in PBS for $3 \mathrm{~d}$ at room temperature to allow dye diffusion. The slices were postfixed with $4 \%$ PFA, washed, and mounted using an antifading water-based mounting medium (Biomeda). The neurons were imaged using an Axioplan 2 imaging microscope (Zeiss) equipped with an ApoTome (Zeiss). Each neuron was first imaged with a $20 \times$ objective with a $z$-sectioning of $0.975 \mu \mathrm{m}$. The morphological reconstruction of the neurons and their processes was achieved using the Neurolucida software (MicroBrightField), and the Sholl analysis (Sholl, 1953), as well as the number, length, and volume of dendrites was performed with the Neuroexplorer software (MicroBrightField). The spine density of the pyramidal cells was measured for mid-apical dendrites using a LSM510 Meta confocal microscope (Zeiss) with a $40 \times$ water-immersion objective and a zoom 4 , and by $z$-sectioning at $0.3 \mu \mathrm{m}$. The statistical analysis was performed using GraphPad Prism 4. All data shown are presented as \pm SEM. The data obtained were compared between two different experimental conditions using a twotailed Student's $t$ test. All experiments were performed and analyzed without the experimenter knowing the genotype of the preparation.

\section{Results}

\section{Increased hippocampal LTP in Glu-CB1-KO mice}

Presynaptically located and activated CB1 receptor on glutamatergic terminals inhibits the release of glutamate (Kano et al., 2009; Castillo et al., 2012). Thus, it can be assumed that glutamatergic synapses where the $\mathrm{CB} 1$ receptor is genetically deleted (Glu-CB1-KO mice) will show increased glutamatergic synaptic transmission following neuronal activation. This may affect the induction of NMDA receptor-dependent LTP. Indeed, we observed that LTP was significantly increased (Fig. $1 A ; p<0.001, t$ test) in Glu-CB1-KO mice ( $n=9$ slices from 5 mice) compared with littermate controls ( $n=9$ slices from 5 mice) for the whole range of $60 \mathrm{~min}$ after tetanization. Basal transmission was analyzed by modulation of the stimulus strength and the corresponding fEPSP size (Fig. 1B). Basal transmission is compromised at higher currents and comparable with controls at low current values: the slope values of Glu-CB1-KO mice stayed significantly lower at $125 \mu \mathrm{A}(p=0.045), 150 \mu \mathrm{A}(p=0.03), 175 \mu \mathrm{A}(p=0.015)$, and $200 \mu \mathrm{A}(p=0.009)$. In addition, we evaluated fEPSP responses during TBS as an indicator for the ability to follow the TBS was analyzed in GABA-CB1-KO compared with the corresponding controls. No significant differences were observed here ( $p>0.1$ for all conditions tested, ANOVA, followed by Fisher's post hoc test).

The ability of the presynapse to react adequately to two temporary fast following stimuli was probed with PPF. The relation between the value of the second slope and the first slope is shown 
A

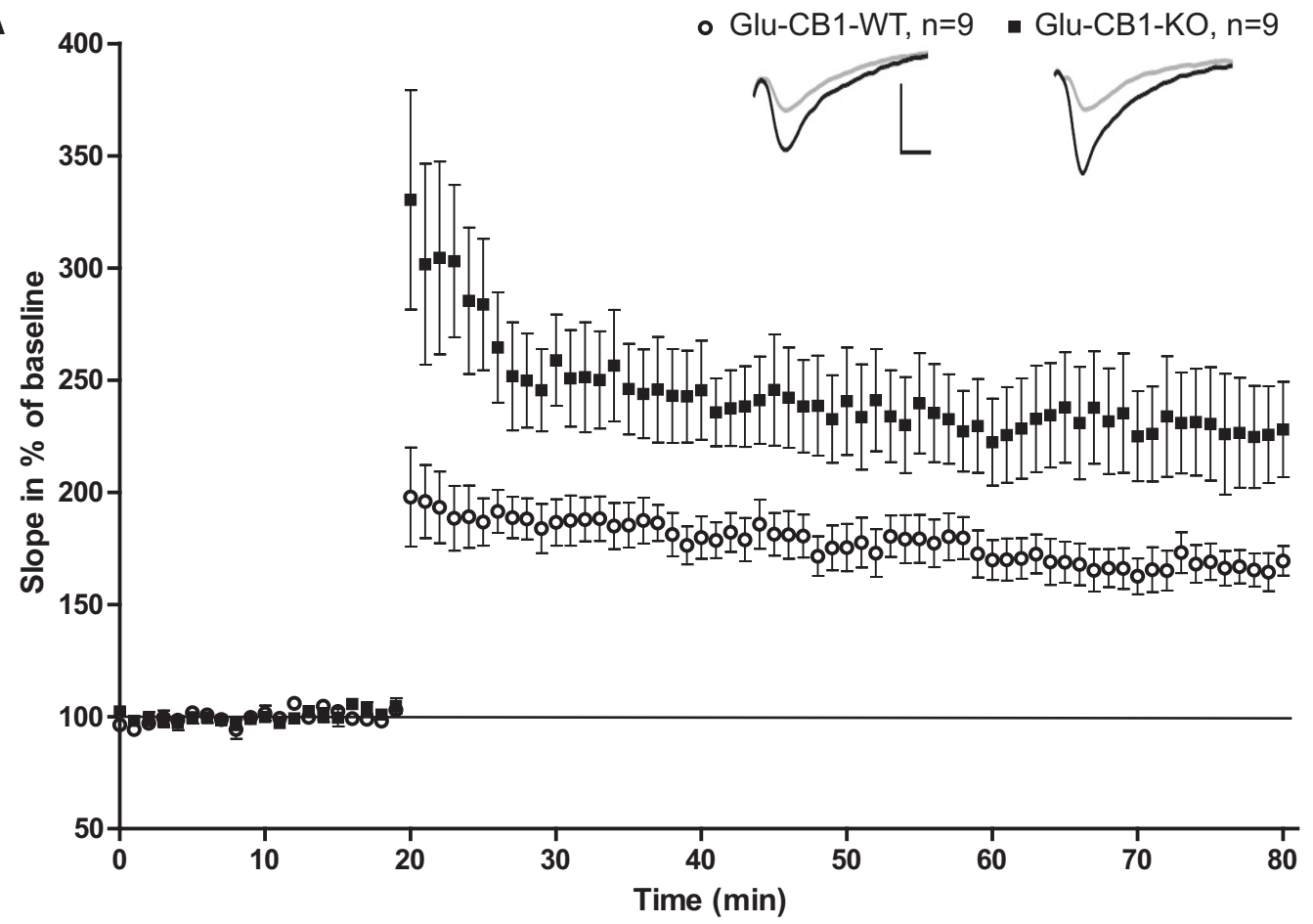

B

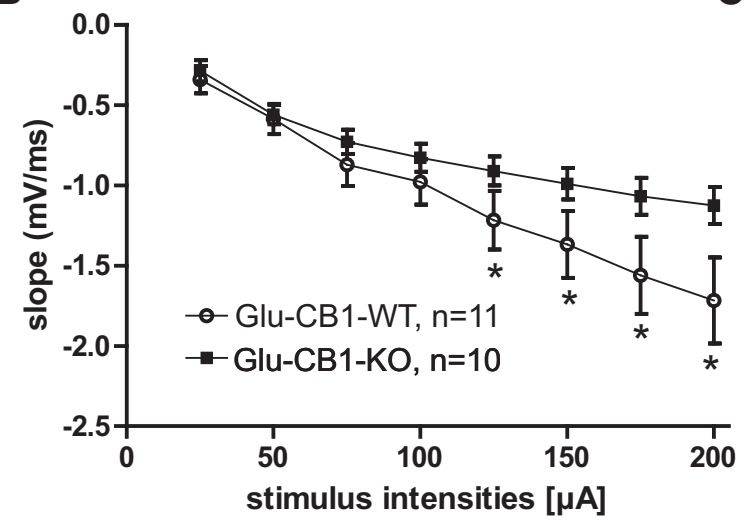

C

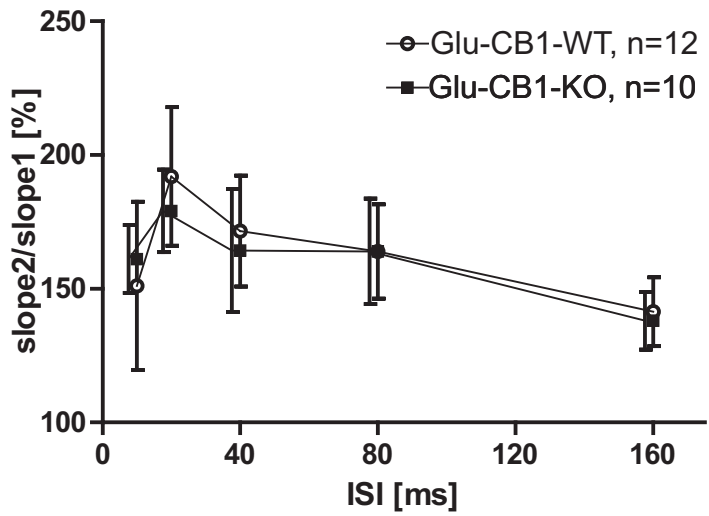

Figure 1. Baseline synaptic transmission and LTP experiments in Glu-CB1-K0 mice. Summary of a set of extracellular fEPSP recordings in Glu-CB1-K0 mice and their WT littermates. A, LTP with 20 min baseline recording, followed by TBS inducing a long lasting potentiation in both genotypes. Glu-CB1-K0 mice showed an increased potentiation, significant for 60 min after tetanization. Insets, Original traces of representative individual experiments $5 \mathrm{~min}$ before (gray), and $55 \mathrm{~min}$ after (black) TBS application. Vertical scale bar, $1 \mathrm{mV}$; horizontal scale bar, $4 \mathrm{~ms}$. B, EPSP slopes plotted against stimulus intensities showing significantly decreased slopes from 125 to $200 \mu$ A for Glu-CB1-K0 mice $(p<0.05)$. C, Glu-CB1-K0 mice showed comparable PPF ratios to control littermates. Two-tailed Student's $t$ test. Error bars $=$ SEM.

with different interstimulus intervals (ISI) in Figure 1C. PPF was not altered between genotypes at any ISI values tested (Fig. 1C).

These results demonstrate that CB1 receptor located on glutamatergic neurons has a strong effect on LTP by limiting the amount of possible potentiation, but it only mildly influences basal synaptic transmission in the mouse hippocampus and does not influence the glutamate release for processes of short-term plasticity, such as PPF.

\section{Decreased hippocampal LTP in GABA-CB1-KO mice}

In the hippocampus, the $\mathrm{CB} 1$ receptor is expressed in excitatory (glutamatergic), as well as in inhibitory (GABAergic) cells (Marsicano and Lutz, 1999), but the amount of CB1 receptor mRNA and protein on GABAergic neurons greatly outnumbers that on glutamatergic cells (Steindel et al., 2013). We therefore also investigated the role of $\mathrm{CB} 1$ receptor on GABAergic neurons for basal synaptic transmission and LTP. We performed electrophysiological recordings using 8-week-old GABA-CB1-KO mice, in which $\mathrm{CB} 1$ receptor is specifically deleted in forebrain GABAergic neurons (Monory et al., 2006) and their WT littermates. The summary data of all experiments are shown as mean with a stable baseline $(3 \pm 1 \%$; Fig. 2). Unlike mice with $\mathrm{CB} 1$ receptor deficiency in the entire animal (Bohme et al., 2000; Jacob et al., 2012), GABA-CB1-KO mice $(n=10)$ showed a significantly $(p<0.05)$ decreased potentiation starting from $4 \mathrm{~min}$ after tetanization until the end of the experiment compared with littermate controls ( $n=10$; Fig. $2 A)$.

Basal transmission was analyzed in the same way as for GluCB1-KO mice by modulation of the stimulus strength and the 
A
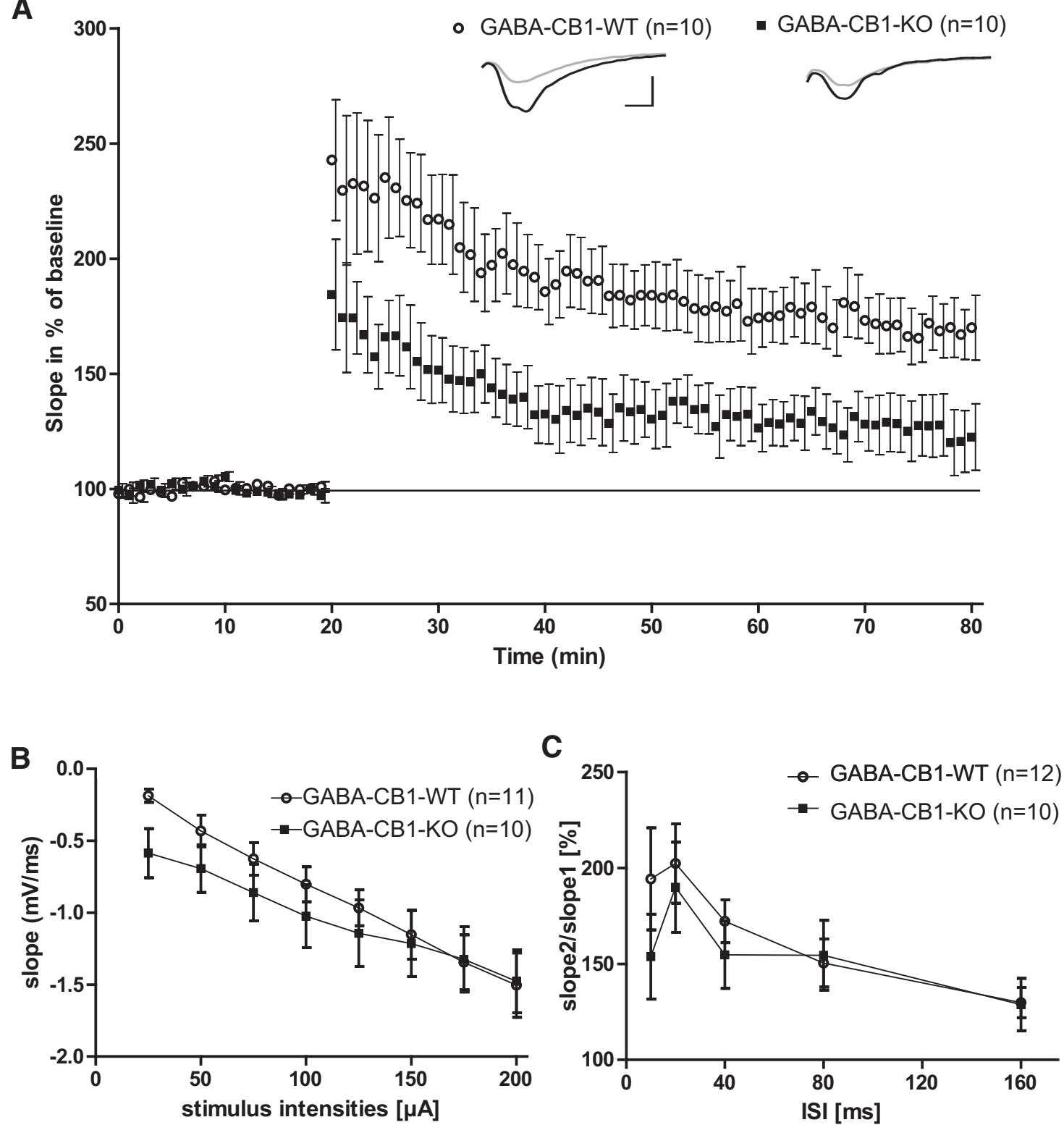

Figure 2. Baseline synaptic transmission and LTP induction in GABA-CB1-K0 mice. Summary of a set of extracellular fEPSP recordings in GABA-CB1-K0 mice and their WT littermates. A, LTP with 20 min of baseline recording, followed by a TBS inducing a long lasting potentiation in both genotypes. GABA-CB1-K0 mice showed a decreased potentiation, significant from 4 min after tetanization. Insets, Original traces of representative individual experiments 5 min before (gray), and 55 min after (black) TBS application. Vertical scale bar, $1 \mathrm{mV}$; horizontal scale bar, $4 \mathrm{~ms}$. B, EPSP slopes plotted against stimulus intensities showing significantly increased slopes at 25 and $50 \mu \mathrm{A}$ for GABA-CB1-K0 mice, $(p<0.05)$. C, GABA-CB1-K0 mice showed comparable PPF ratios to control littermates ( $p=0.11, t$ test). Two-tailed Student's $t$ test.

corresponding fEPSP size (Fig. $2 B$ ). The slope was significantly increased at $25 \mu \mathrm{A}(p=0.0008)$ and $50 \mu \mathrm{A}(p=0.023)$ stimulus strength in GABA-CB1-KO compared with littermate controls. With the application of higher currents, the responses of GABACB1-KO were indistinguishable from controls. In PPF experiments, both genotypes showed comparable values with a maximum at $20 \mathrm{~ms}$ ISI (Fig. 2C). There is a tendency for higher values in controls between 10 and $40 \mathrm{~ms}$, but it does not reach statistical significance ( $p=0.11, t$ test). In addition, we evaluated fEPSP responses during TBS as an indicator for the ability to follow the TBS. This was evaluated in Glu-CB1-KO mice compared with the corresponding controls. No significant differences were observed here ( $p>0.1$ for all conditions tested, ANOVA, followed by Fisher's post hoc test).
Together, these results showed a strong effect of CB1 receptor in GABAergic neurons on LTP, but no statistical significant effect on basal synaptic transmission.

\section{Dendritic morphology of Glu-CB1-KO and GABA-CB1-KO mice}

Because our electrophysiological experiments revealed an opposite phenotype in these two mutant lines, we next wondered whether the dendritic morphology of CA1 pyramidal neurons of the hippocampus would also be altered in the corresponding conditional CB1 receptor mutant mice. This has so far not been explored in the context of CB1 receptor signaling. Pyramidal neurons in the CA1 region were labeled with DiI in acute hippocampal slices (Fig. $3 A-C$ ). In view of their different morphol- 
A

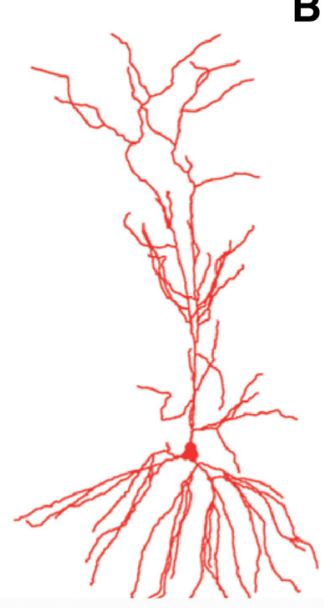

D

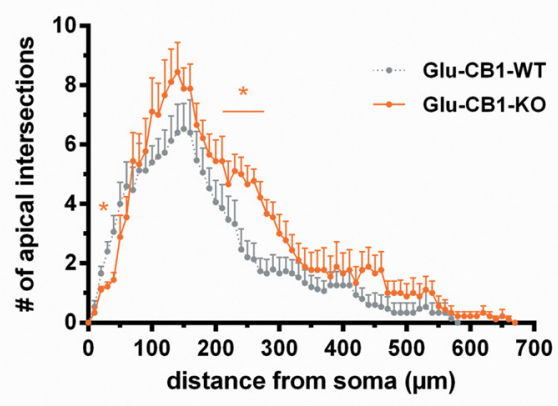

$\mathbf{F}$

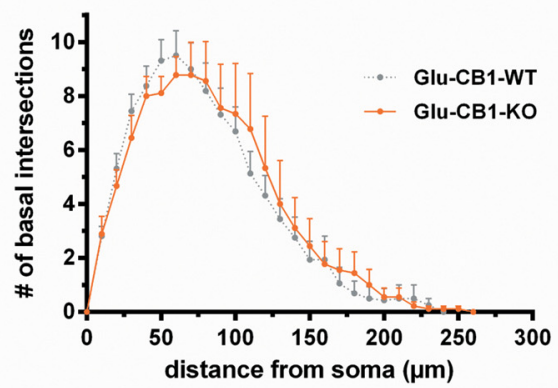

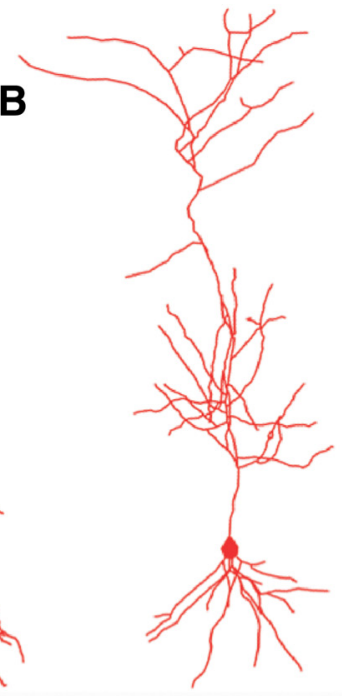

C

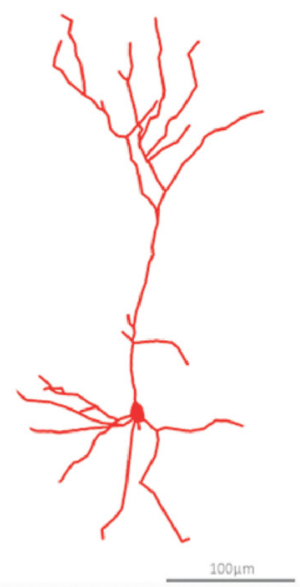

E

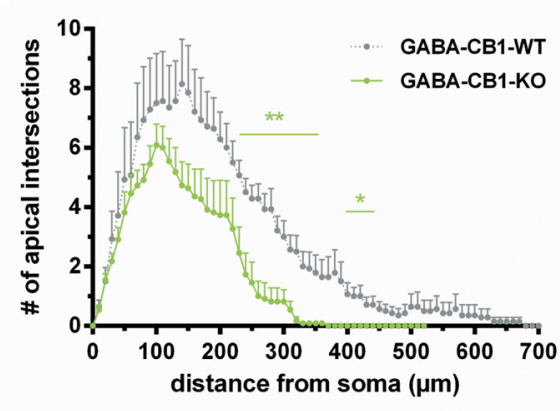

G

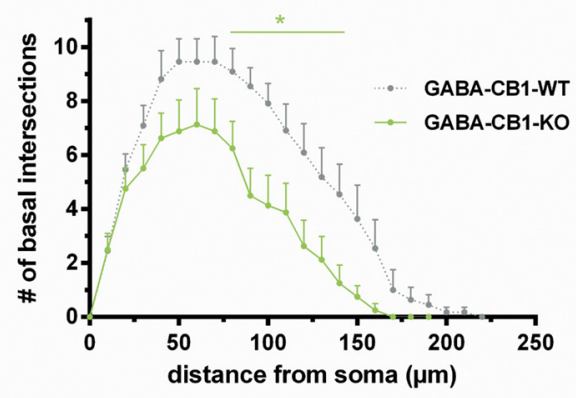

Figure 3. Morphology and Sholl analysis of Glu-CB1-K0 and GABA-CB1-K0 mice. $\boldsymbol{A}$, Representative image of a Dil-labeled CA1 pyramidal neuron of Glu-CB1-K0 mice. $\boldsymbol{B}$, Representative image of a Dil-labeled CA1 pyramidal neuron of a GABA-CB1-WT mouse. Note that there was no significant difference between CA1 pyramidal neuron morphology of GABA-CB1-WT and Glu-CB1-WT mice. C, Representative image of a Dil-labeled CA1 pyramidal neuron of GABA-CB1-K0 mice. Scale bar, $100 \mu \mathrm{m}$. D, Sholl analysis of Glu-CB1-K0 mice versus WT littermate controls at apical dendrites of CA1 hippocampal neurons. $E$, Sholl analysis of GABA-CB1-K0 mice versus WT littermate controls at apical dendrites of CA1 hippocampal neurons. $F$, Sholl analysis of Glu-CB1-K0 mice versus WT littermate controls at basal dendrites of CA1 hippocampal neurons. G, Sholl analysis of GABA-CB1-K0 mice versus WT littermate controls at basal dendrites of CA1 hippocampal neurons. Two-tailed Student's $t$ test; ${ }^{*} p<0.05,{ }^{* *} p<0.01$; error bars $=$ SEM.

ogy and connectivity, we analyzed the complexity of apical and basal dendrites separately. The apical and basal dendritic complexity was analyzed up to a distance of 700 and $300 \mu \mathrm{m}$ from the cell body, respectively. The total dendritic complexity in animals lacking CB1 receptor on glutamatergic neurons (Glu-CB1-KO) was significantly increased compared with WT littermate controls in the apical dendrites (Glu-CB1-WT: $129.9 \pm 14.4$ intersections/neuron, $n=14$; Glu-CB1-KO: $176.1 \pm 13.1, n=8$; $p=$ $0.044, t$ test). The total dendritic complexity in basal dendrites was comparable between Glu-CB1-KO and controls (Glu-CB1WT: $97.4 \pm 8.3, n=16$; Glu-CB1-KO: $85.3 \pm 9.9, n=8$; $p=$ $0.379, t$ test). A more detailed Sholl analysis was performed by plotting the number of intersections against the distance from the cell body. These results confirmed a general increase of dendritic complexity with a local significant range $(240-290 \mu \mathrm{m} ; p<0.05)$ in the apical part (Fig. 3D), but not in the basal dendritic segment (Fig. 3F). In these mice, the density of dendritic spines on excitatory, pyramidal neurons was also analyzed at the mid-apical 
A

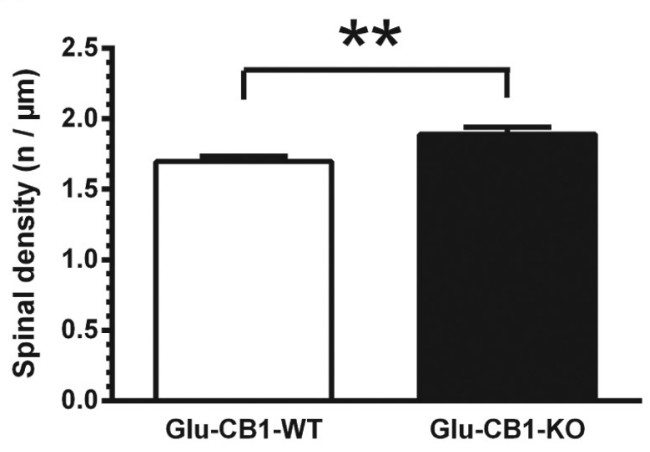

C

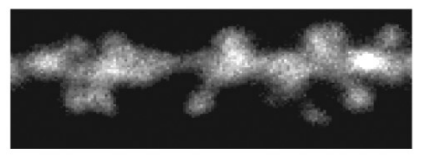

Glu-CB1-KO

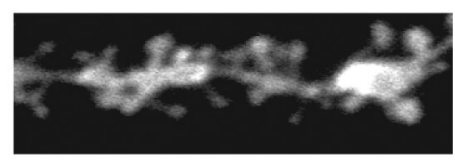

Glu-CB1-WT

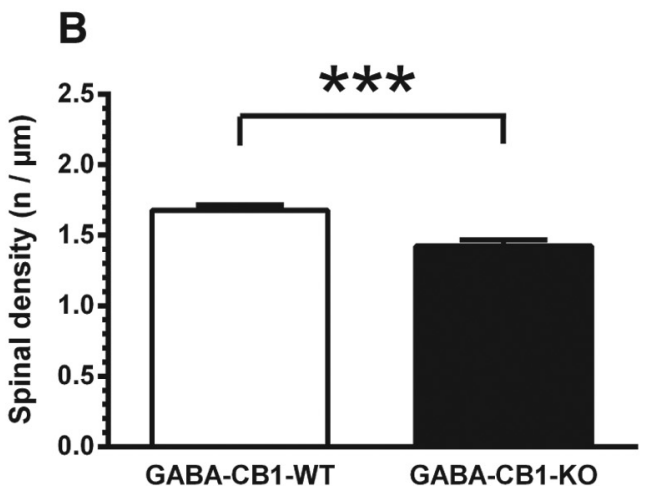

GABA-CB1-WT

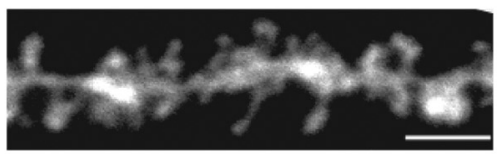

GABA-CB1-KO

Figure 4. Dendritic spine density in Glu-CB1-K0 and GABA-CB1-K0 mice. $A$, Spine density of CA1 hippocampal neurons from the mid-apical dendrites in Glu-CB1-K0 mice versus WT littermate controls. $\boldsymbol{B}$, Spine density of CA1 hippocampal neurons from the mid-apical dendrites in GABA-CB1-K0 mice versus WT littermate controls. $\boldsymbol{C}$, Individual examples of spines on mid-apical dendrites for all three genotypes. Statistics: $t$ test; ${ }^{* *} p<0.01 ;{ }^{* * *} p<0.001$; error bars $=$ SEM.

portion of the apical dendrite (Fig. 4). Spine density was significantly increased in Glu-CB1-KO mice (Glu-CB1-WT: $1.70 \pm$ 0.04, $n=31$; vs Glu-CB1-KO: $1.89 \pm 0.05, n=29, p=0.0036, t$ test; Fig. $4 A$ ).

In contrast to these findings, the dendritic complexity of pyramidal cells in animals lacking the $\mathrm{CB} 1$ receptor on GABAergic neurons was significantly reduced in both apical (GABA-CB1WT: $168.8 \pm 22.5, n=13$; GABA-CB1-KO: $100.6 \pm 11.6, n=11$; $p=0.019, t$ test $)$ and basal dendrites (GABA-CB1-WT: $109.1 \pm$ 9.7, $n=11$; GABA-CB1-KO: $66.0 \pm 10.9 n=8 ; p=0.009, t$ test $)$. These results were supported by the Sholl analysis, showing decreased dendritic complexity locally in the basal and apical compartment (Fig. $3 E, G$ ). Significant differences were found between 230 and $440 \mu \mathrm{m}$ in the apical dendrites $(p<0.05, t$ test). We also compared the density of dendritic spines at the midapical portion of the apical dendrite of GABA-CB1-KO animals and their WT littermates and found a significant reduction compared with control neurons (GABA-CB1-WT: $1.68 \pm 0.04, n=$ 33; GABA-CB1-KO: $1.42 \pm 0.04, n=30 ; p=0.00003, t$ test; Fig. $4 B$, cf. $C$ for original pictures of mid-apical dendritic segments for all genotypes).

\section{Discussion}

Memory restricting molecules might function as checkpoints determining the occurrence, the rate and the specificity at which changes in neuronal connectivity are either implemented or prevented. Thereby, these memory controlling proteins might ensure that only relevant features of an event are stored (Abel et al., 1998; Zagrebelsky and Korte, 2014). This memory barrier is of special importance for animals in general and humans in particular, since it is a hallmark of higher cognitive function to select salient information from a noisy background by attending to and remembering only the most critical features (Zagrebelsky and Korte, 2014). It is a clear advantage for individuals to filter facts that are important for survival, rather than randomly storing all encountered information into their long-term memory. More- over, it might be even more important to consolidate the most important facts and features and protect them from changes.

In this context, the endocannabinoid system might be of high relevance, as we show here the potential of the CB1 receptor to calibrate synaptic potentiation and dendritic morphology via the GABAergic and the glutamatergic system. LTP, an increase in synaptic strength resulting from synchronous or high-frequency stimulation of a neuronal pathway, is thought to be an electrophysiological correlate of learning and memory processes (Citri and Malenka, 2008). For the highly complex task of memory formation to properly operate, the brain has to maintain a well tuned activity; a refined and dynamic balance of excitation and inhibition (Hensch and Fagiolini, 2005). The CB1 receptor, present both in GABAergic and glutamatergic terminals, is particularly well positioned to accomplish this goal, as the endocannabinoids act as retrograde signals to tune neurotransmission in a negative feedback (Castillo et al., 2012).

Our study revealed that the lack of CB1 receptor in cortical glutamatergic neurons facilitates hippocampal LTP formation, whereas inactivation of CB1 receptor function in forebrain GABAergic neurons leads to diminished hippocampal LTP formation. How can this dichotomy be reconciled? It was shown that LTP induces the production of endocannabinoids (Stella et al., 1997; Castillo et al., 2012). They are synthesized at the postsynapse of activated glutamatergic neurons, and then travel in a retrograde manner to local presynaptic $\mathrm{CB} 1$ receptors, located on both glutamatergic and GABAergic terminals, which both can innervate the endocannabinoid-producing postsynaptic glutamatergic neuron. Upon binding of the endocannabinoids to the presynaptic CB1 receptor, neurotransmission is suppressed. In the hippocampus, short-term depolarization-induced suppression of glutamate transmission and GABA transmission was reported, in addition to a long-term suppression at the GABAergic synapse, called inhibitory LTD (Chevaleyre and Castillo, 2004; for review, see Castillo et al., 2012). Thus, the endocannabinoid 
system represents an important negative feedback mechanism at both glutamatergic and GABAergic synapses. This includes homosynaptic and heterosynaptic processes. We found evidence that in the Glu-CB1-KO (the CB1 receptor is deleted at glutamatergic terminals) the endocannabinoid-mediated transient suppression of neurotransmitter release will not be accomplished, although endocannabinoids are produced (due to the LTP stimulation protocol), but the target, the presynaptic CB1 receptor, is missing. Therefore, glutamate release and transmission are not suppressed. Consequently, excitability of glutamatergic neurons will be increased in Glu-CB1-KO, and LTP is facilitated compared with WT controls. In case of $\mathrm{CB} 1$ receptor deletion at the GABAergic terminal in GABA-CB1-KO, the postsynaptic glutamatergic neurons can produce endocannabinoids (due to the LTP stimulation protocol), but the presynaptic incoming GABAergic terminal lacks the CB1 receptor. Therefore, GABAergic inhibition is not suppressed, and the glutamatergic neurons are less excitable, leading to decreased LTP.

We did not only observe increased and decreased LTP in the Glu-CB1-KO and GABA-CB1-KO, respectively, compared with controls, but also alterations in spine density and dendritic morphology. The long-term loss of CB1 receptor in glutamatergic neurons, which started shortly after the last mitosis of the glutamatergic neurons during development (Mulder et al., 2008), appears to cause a hyperexcitable state in Glu-CB1-KO, leading to increased spine density and dendritic branching. Decreased spine density and dendritic branching was observed in the adult GABA-CB1-KO, where the loss of CB1 receptor also occurred during embryonic development (Berghuis et al., 2007). This suggests the presence of a hypoexcitable state in GABA-CB1-KO. The general hyperexcitable state of Glu-CB1-KO is well documented by the increased susceptibility to kainic acid-induced seizures (Monory et al., 2006). Using the same seizure model, GABA-CB1-KO, however, did not show altered seizure susceptibility. The reasons for this have not yet been clarified, but it is noteworthy that $\mathrm{CB} 1$ receptor is specifically expressed on cholecystokinin-positive interneurons.

The dichotomy of LTP and morphological phenotypes reported in this study is congruent with behavioral investigations, where we frequently observed opposite phenotypes. In Glu-CB1$\mathrm{KO}$, for example, object exploration (Häring et al., 2011), impulsivity (Lafenêtre et al., 2009), feeding response (Bellocchio et al., 2010), and active fear coping (Metna-Laurent et al., 2012) are decreased, whereas these behavioral outcomes are increased in GABA-CB1-KO. Based on these observations, such opposite phenotypes might be predicted for other behavioral or cellular experimental paradigms.

It is interesting to note that in global $\mathrm{CB} 1$ receptor-deficient mice $(\mathrm{CB} 1-\mathrm{KO})$, where both the low to moderate $\mathrm{CB} 1$ receptor expression in glutamatergic pyramidal neurons and the very high CB1 receptor expression in GABAergic interneurons is missing, the phenotype is similar to that observed in Glu-CB1-KO. This has been reported for several behavioral phenotypes (Monory et al., 2006; Kamprath et al., 2009; Metna-Laurent et al., 2012), and facilitated hippocampal LTP (Bohme et al., 2000). In addition, CB1 receptor antagonism also facilitates hippocampal (Hoffman et al., 2007) and prefrontal cortex (Auclair et al., 2000) LTP. These observations suggest that CB1 receptor function in pyramidal cells "overwrites" the function of interneurons in terms of LTP generation. Although CB1 receptor expression in pyramidal cells is much lower than in the GABAergic cells, pyramidal cells greatly outnumber GABAergic interneurons (of which approximately one third expresses the CB1 receptor; Marsicano and Lutz,
1999; Steindel et al., 2013). Moreover, the computational potency of the pyramidal cells is much higher, too: they receive up to 30,000 inputs and target 10,000-60,000 other neurons themselves, whereas interneurons receive a maximum of 15,000 inputs and have up to 5000 synaptic targets (Buhl and Whittington, 2007). Consequently, CA1 pyramidal neurons receive more excitatory than inhibitory inputs. Finally, our recent data of CB1 receptor-mediated intracellular signaling showed that in the hippocampus agonist stimulation of CB1 receptor is more effectively transduced to G-protein activation in glutamatergic than in GABAergic cells (Steindel et al., 2013). Therefore, it is reasonable to argue that even with lower CB1 receptor expression levels, the higher connectivity of pyramidal neurons and the more effective signal transduction mechanisms of CB1 receptor in these cells lend this neuronal population a powerful control over local synaptic strength.

In the medial prefrontal cortex, $\mathrm{CB} 1-\mathrm{KO}$ mice showed decreased dendritic branching and dendritic length (Hill et al., 2011), and dendritic area and number of spines are decreased in the motor cortex (Ballesteros-Yáñez et al., 2007). In the basolateral amygdala, however, dendritic branching and length is increased in CB1-KO mice (Hill et al., 2011).

Both in vivo and in vitro applications of $\mathrm{CB} 1$ receptor agonists prevent the formation of hippocampal LTP (Paton et al., 1998; Hoffman et al., 2007; Fan et al., 2010), consistent with the memory impairments observed after systemic CB1 receptor agonist (e.g., THC) treatments in animals and humans. Chronic highdose THC treatments lead to a strong downregulation of CB1 receptor in GABAergic neurons (Puighermanal et al., 2013), and to a decrease of $\mathrm{CB} 1$ receptor-mediated suppression of GABA, but not glutamate transmission (Hoffman et al., 2007). In congruency, the amnesic effects of acute high THC dose was not present in GABA-CB1-KO (Puighermanal et al., 2009), and chronic high-dose THC did not induce cognitive deficits in GABA-CB1-KO (Puighermanal et al., 2013). In the light that chronic THC downregulates CB1 receptor in GABAergic neurons in particular, one would expect a decrease of LTP formation, but an abolishment of LTP is observed (Hoffman et al., 2007). Thus, further investigations are needed to clarify this issue.

The well functioning endocannabinoid and CB1 receptor signaling helps to maintain a stable and balanced activity at neuronal and circuit levels, thereby representing an important homeostatic factor of the nervous system. Neuronal excitability relies on the summation of excitatory and inhibitory signals, both of which are controlled by endocannabinoids in the cerebral cortex and hippocampus. By deleting CB1 receptor from cortical/ hippocampal glutamatergic or forebrain GABAergic neurons, an activity-related control mechanism of the release of glutamate or GABA, respectively, is removed. Consequently, the excitability of the whole system slightly shifts upward or downward, and reaches a new stable equilibrium state, a new allostatic set point, which is opposite to each other in Glu-CB1-KO and GABA-CB1$\mathrm{KO}$, but which both represent a nonfavorable and pathophysiological state, leading to cellular and behavioral alterations. Previous works have already reported the homeostatic role of the hippocampal endocannabinoid system after long-term neuronal silencing (Kim and Alger, 2010), and after strong neuronal activity (Bojnik et al., 2012). It remains to be investigated how the new allostatic set points in Glu-CB1-KO and GABA-CB1-KO are reached and regulated by possibly non-endocannabinoid-mediated mechanisms. 


\section{References}

Abel T, Martin KC, Bartsch D, Kandel ER (1998) Memory suppressor genes: inhibitory constraints on the storage of long-term memory. Science 279: 338-341. CrossRef Medline

Auclair N, Otani S, Soubrie P, Crepel F (2000) Cannabinoids modulate synaptic strength and plasticity at glutamatergic synapses of rat prefrontal cortex pyramidal neurons. J Neurophysiol 83:3287-3293. Medline

Ballesteros-Yáñez I, Valverde O, Ledent C, Maldonado R, DeFelipe J (2007) Chronic cocaine treatment alters dendritic arborization in the adult motor cortex through a CB1 cannabinoid receptor-dependent mechanism. Neuroscience 146:1536-1545. CrossRef Medline

Bellocchio L, Lafenêtre P, Cannich A, Cota D, Puente N, Grandes P, Chaouloff F, Piazza PV, Marsicano G (2010) Bimodal control of stimulated food intake by the endocannabinoid system. Nat Neurosci 13:281-283. CrossRef Medline

Berghuis P, Rajnicek AM, Morozov YM, Ross RA, Mulder J, Urbán GM, Monory K, Marsicano G, Matteoli M, Canty A, Irving AJ, Katona I, Yanagawa Y, Rakic P, Lutz B, Mackie K, Harkany T (2007) Hardwiring the brain: endocannabinoids shape neuronal connectivity. Science 316:12121216. CrossRef Medline

Bliss TV, Collingridge GL (1993) A synaptic model of memory: long-term potentiation in the hippocampus. Nature 361:31-39. CrossRef Medline

Bohme GA, Laville M, Ledent C, Parmentier M, Imperato A (2000) Enhanced long-term potentiation in mice lacking cannabinoid CB1 receptors. Neuroscience 95:5-7. CrossRef Medline

Bojnik E, Turunç E, Armağan G, Kanıt L, Benyhe S, Yalçın A, Borsodi A (2012) Changes in the cannabinoid (CB1) receptor expression level and G-protein activation in kainic acid induced seizures. Epilepsy Res 99:64-68. CrossRef Medline

Buhl E, Whittington M (2007) Local circuits. In: The hippocampus book (Amaral D, Andersen P, Morris R, Bliss T, O’Keefe J, eds). New York: Oxford UP.

Carlson G, Wang Y, Alger BE (2002) Endocannabinoids facilitate the induction of LTP in the hippocampus. Nat Neurosci 5:723-724. CrossRef Medline

Castillo PE, Younts TJ, Chávez AE, Hashimotodani Y (2012) Endocannabinoid signaling and synaptic function. Neuron 76:70-81. CrossRef Medline

Chevaleyre V, Castillo PE (2004) Endocannabinoid-mediated metaplasticity in the hippocampus. Neuron 43:871-881. CrossRef Medline

Citri A, Malenka RC (2008) Synaptic plasticity: multiple forms, functions, and mechanisms. Neuropsychopharmacology 33:18-41. CrossRef Medline

Fan N, Yang H, Zhang J, Chen C (2010) Reduced expression of glutamate receptors and phosphorylation of CREB are responsible for in vivo Delta9-THC exposure-impaired hippocampal synaptic plasticity. J Neurochem 112:691-702. CrossRef Medline

Goebbels S, Bormuth I, Bode U, Hermanson O, Schwab MH, Nave KA (2006) Genetic targeting of principal neurons in neocortex and hippocampus of NEX-Cre mice. Genesis 44:611-621. CrossRef Medline

Häring M, Kaiser N, Monory K, Lutz B (2011) Circuit specific functions of cannabinoid CB1 receptor in the balance of investigatory drive and exploration. PloS one 6:e26617. CrossRef Medline

Hensch TK, Fagiolini M (2005) Excitatory-inhibitory balance and critical period plasticity in developing visual cortex. Prog Brain Res 147:115-124. CrossRef Medline

Hill MN, Hillard CJ, McEwen BS (2011) Alterations in corticolimbic dendritic morphology and emotional behavior in cannabinoid CB1 receptor-deficient mice parallel the effects of chronic stress. Cereb Cortex 21:2056-2064. CrossRef Medline

Hoffman AF, Oz M, Yang R, Lichtman AH, Lupica CR (2007) Opposing actions of chronic Delta9-tetrahydrocannabinol and cannabinoid antagonists on hippocampal long-term potentiation. Learn Mem 14:63-74. CrossRef Medline

Jacob W, Marsch R, Marsicano G, Lutz B, Wotjak CT (2012) Cannabinoid $\mathrm{CB} 1$ receptor deficiency increases contextual fear memory under highly aversive conditions and long-term potentiation in vivo. Neurobiol Learn Mem 98:47-55. CrossRef Medline

Kamprath K, Plendl W, Marsicano G, Deussing JM, Wurst W, Lutz B, Wotjak CT (2009) Endocannabinoids mediate acute fear adaptation via glutamatergic neurons independently of corticotropin-releasing hormone signaling. Genes Brain Behav 8:203-211. CrossRef Medline
Kano M, Ohno-Shosaku T, Hashimotodani Y, Uchigashima M, Watanabe M (2009) Endocannabinoid-mediated control of synaptic transmission. Physiol Rev 89:309-380. CrossRef Medline

Kim J, Alger BE (2010) Reduction in endocannabinoid tone is a homeostatic mechanism for specific inhibitory synapses. Nat Neurosci 13:592-600. CrossRef Medline

Kleppisch T, Wolfsgruber W, Feil S, Allmann R, Wotjak CT, Goebbels S, Nave KA, Hofmann F, Feil R (2003) Hippocampal cGMP-dependent protein kinase I supports an age-and protein synthesis-dependent component of long-term potentiation but is not essential for spatial reference and contextual memory. J Neurosci 23:6005-6012. Medline

Lafenêtre P, Chaouloff F, Marsicano G (2009) Bidirectional regulation of novelty-induced behavioral inhibition by the endocannabinoid system. Neuropharmacology 57:715-721. CrossRef Medline

Malenka RC, Bear MF (2004) LTP and LTD: an embarrassment of riches. Neuron 44:5-21. CrossRef Medline

Marsicano G, Lafenêtre P (2009) Roles of the endocannabinoid system in learning and memory. Curr Top Behav Neurosci 1:201-230. CrossRef Medline

Marsicano G, Lutz B (1999) Expression of the cannabinoid receptor CB1 in distinct neuronal subpopulations in the adult mouse forebrain. Eur J Neurosci 11:4213-4225. CrossRef Medline

Marsicano G, Wotjak CT, Azad SC, Bisogno T, Rammes G, Cascio MG, Hermann H, Tang J, Hofmann C, Zieglgänsberger W, Di Marzo V, Lutz B (2002) The endogenous cannabinoid system controls extinction of aversive memories. Nature 418:530-534. CrossRef Medline

Marsicano G, Goodenough S, Monory K, Hermann H, Eder M, Cannich A, Azad SC, Cascio MG, Gutiérrez SO, van der Stelt M, López-Rodriguez ML, Casanova E, Schütz G, Zieglgänsberger W, Di Marzo V, Behl C, Lutz B (2003) CB1 cannabinoid receptors and on-demand defense against excitotoxicity. Science 302:84-88. CrossRef Medline

Massa F, Mancini G, Schmidt H, Steindel F, Mackie K, Angioni C, Oliet SH, Geisslinger G, Lutz B (2010) Alterations in the hippocampal endocannabinoid system in diet-induced obese mice. J Neurosci 30:6273-6281. CrossRef Medline

Metna-Laurent M, Soria-Gómez E, Verrier D, Conforzi M, Jégo P, Lafenêtre P, Marsicano G (2012) Bimodal control of fear-coping strategies by CB(1) cannabinoid receptors. J Neurosci 32:7109-7118. CrossRef Medline

Monory K, Massa F, Egertová M, Eder M, Blaudzun H, Westenbroek R, Kelsch W, Jacob W, Marsch R, Ekker M, Long J, Rubenstein JL, Goebbels S, Nave KA, During M, Klugmann M, Wölfel B, Dodt HU, Zieglgänsberger W, Wotjak CT, et al. (2006) The endocannabinoid system controls key epileptogenic circuits in the hippocampus. Neuron 51:455-466. CrossRef Medline

Monory K, Blaudzun H, Massa F, Kaiser N, Lemberger T, Schütz G, Wotjak CT, Lutz B, Marsicano G (2007) Genetic dissection of behavioural and autonomic effects of delta(9)-tetrahydrocannabinol in mice. PLoS Biol 5:e269. CrossRef Medline

Mulder J, Aguado T, Keimpema E, Barabás K, Ballester Rosado CJ, Nguyen L, Monory K, Marsicano G, Di Marzo V, Hurd YL, Guillemot F, Mackie K, Lutz B, Guzmán M, Lu HC, Galve-Roperh I, Harkany T (2008) Endocannabinoid signaling controls pyramidal cell specification and longrange axon patterning. Proc Natl Acad Sci U S A 105:8760-8765. CrossRef Medline

Navakkode S, Korte M (2014) Pharmacological activation of CB1 receptor modulates long term potentiation by interfering with protein synthesis. Neuropharmacology 79:525-533. CrossRef Medline

Paton GS, Pertwee RG, Davies SN (1998) Correlation between cannabinoidmediated effects on paired pulse depression and induction of long term potentiation in the rat hippocampal slice. Neuropharmacology 37:1123-1130. CrossRef Medline

Puighermanal E, Marsicano G, Busquets-Garcia A, Lutz B, Maldonado R, Ozaita A (2009) Cannabinoid modulation of hippocampal long-term memory is mediated by mTOR signaling. Nat Neurosci 12:1152-1158. CrossRef Medline

Puighermanal E, Busquets-Garcia A, Gomis-González M, Marsicano G, Maldonado R, Ozaita A (2013) Dissociation of the pharmacological effects of THC by mTOR blockade. Neuropsychopharmacology 38:1334-1343. CrossRef Medline

Riedel G, Davies SN (2005) Cannabinoid function in learning, memory and plasticity. Handb Exp Pharmacol 168:445-477. CrossRef Medline 
Rösch H, Schweigreiter R, Bonhoeffer T, Barde YA, Korte M (2005) The neurotrophin receptor p75NTR modulates long-term depression and regulates the expression of AMPA receptor subunits in the hippocampus. Proc Natl Acad Sci U S A 102:7362-7367. CrossRef Medline

Roth-Alpermann C, Morris RG, Korte M, Bonhoeffer T (2006) Homeostatic shutdown of long-term potentiation in the adult hippocampus. Proc Natl Acad Sci U S A 103:11039-11044. CrossRef Medline

Ruehle S, Rey AA, Remmers F, Lutz B (2012) The endocannabinoid system in anxiety, fear memory and habituation. J Psychopharmacol 26:23-39. CrossRef Medline

Sholl DA (1953) Dendritic organization in the neurons of the visual and motor cortices of the cat. J Anat 87:387-406. Medline

Steindel F, Lerner R, Häring M, Ruehle S, Marsicano G, Lutz B, Monory K
(2013) Neuron-type specific cannabinoid-mediated G protein signalling in mouse hippocampus. J Neurochem 124:795-807. CrossRef Medline

Stella N, Schweitzer P, Piomelli D (1997) A second endogenous cannabinoid that modulates long-term potentiation. Nature 388:773-778. CrossRef Medline

Turrigiano G (2011) Too many cooks? Intrinsic and synaptic homeostatic mechanisms in cortical circuit refinement. Annu Rev Neurosci 34:89103. CrossRef Medline

Varvel SA, Lichtman AH (2002) Evaluation of CB1 receptor knock-out mice in the Morris water maze. J Pharmacol Exp Ther 301:915-924. CrossRef Medline

Zagrebelsky M, Korte M (2014) Maintaining stable memory engrams: new roles for Nogo-A in the CNS. Neuroscience 283C:17-25. CrossRef Medline 